\title{
The Potential for High Quality Bourbon Coffees From Different Environments
}

\author{
Luisa P Figueiredo ${ }^{1}$, Flávio M Borém², Marcelo Â Cirillo ${ }^{3}$, Fabiana C Ribeiro ${ }^{2}$, Gerson S Giomo ${ }^{4} \&$ \\ Terezinha de J G Salva ${ }^{4}$ \\ ${ }^{1}$ Food Science Department, Federal University of Lavras, Lavras - MG, Brazil \\ ${ }^{2}$ Agricultural Engineering Department, Federal University of Lavras, Lavras - MG, Brazil \\ ${ }^{3}$ Exact Sciences Department, Federal University of Lavras, Lavras - MG, Brazil \\ ${ }^{4}$ Agronomic Institute, Campinas - SP, Brazil \\ Correspondence: Luisa P Figueiredo, Food Science Department, Federal University of Lavras, Lavras - MG, \\ P.O Box 3037, 37200-000, Brazil. E-mail: lupefi@gmail.com
}

Received: June 4, 2013 Accepted: August 8, 2013 Online Published: September 15, 2013

doi:10.5539/jas.v5n10p87 URL: http://dx.doi.org/10.5539/jas.v5n10p87

\begin{abstract}
The Bourbon coffee cultivar has a high potential for producing a quality beverage, which is highly valued in specialty coffee markets. The objective of this study was to verify the occurrence of more promising genotypes for the production of specialty coffees in three different environments. In addition, the chemical composition of the grains was studied with a view toward relating these compounds to the genotypes and environments and to the interaction of these factors. The experimental design included three Brazilian locations in combination with different Arabica coffees, including eleven bourbon and three commercial genotypes. Trigonelline, caffeine and 5-caffeoylquinic acid (5-CQA) from coffee bean samples were analyzed by HPLC, and sensory analyses were performed by professional cuppers accredited by the Coffee Quality Institute. A group of Bourbon genotypes with potential for the production of specialty coffees was identified for each environment assessed. The trigonelline content allowed for discrimination among the three environments studied.
\end{abstract}

Keywords: specialty coffee, chemical composition, sensory analysis

\section{Introduction}

The demand for specialty coffees on the world market has grown in much greater proportions than common coffees. The differentiated quality of specialty coffees is related to the intrinsic quality of the coffee, representing everything that the grains have in terms of chemical compounds which, after roasting, will provide aroma, flavor, acidity, sweetness and bitterness to the beverage.

In general, any Coffea arabica cultivar has potential for the production of high quality coffees. Nevertheless, it has been observed that differentiated flavors and aromas occur with greater frequency in some cultivars. The Bourbon cultivar has intinsic qualities known worldwide, due to its sensory characteristics. It is used for the production of specialty coffees in diverse regions of the world. Nevertheless, different genotypes are described as Bourbon, resulting in the occurrence of crops with totally different traits among themselves, yet called Bourbon (Fazuoli, Guerreiro Filho, Silvarolla, Medina Filho, \& Carvalho, 2005).

The quality of a coffee is expressed differently according to the planting location. It is directly affected by environmental aspects, of both natural and human origin (Avelino et al., 2005; Camargo, 2010; Villarreal et al., 2009; Bertrand et al., 2008).The great variety of coffee types in Brazil is due to cultivation in diverse regions of the country, under the characteristic climatic conditions of each location.

The combination of genetic and environmental factors affects the chemical composition of coffees, which in turn affects the quality of the final product. Thus, the quality and acceptability of the coffee are also directly related to the chemical composition of the grains. Many studies have attempted to understand the relationship between the chemical composition of the green coffee beans and the quality of the beverage in the search for substances or precursors that could affect its acceptance or rejection (Farah, Monteiro, Calado, Franca, \& Trugo, 2006; Franca, Mendonça, \& Oliveira, 2005). Some studies have sought to correlate the levels of some chemical compounds, such 
as caffeine, trigonelline and chlorogenic acids, with species discrimination, assessment of degree of roasting, coffee quality and coffee functional properties (Bicchi, Binello, Pellegrino, \& Vanni, 1995; Casal, Oliveira \& Ferreira, 2000; Mazzafera \& Carvalho, 1992). Other studies have sought to relate these chemical compounds with potential descriptors of the expression of the quality of coffee genotypes in different environments. Avelino et al. (2005) discriminated the environments of Santa Maria de Dota and Orosi, in Costa Rica, by means of quantification of the chemical compounds of caffeine, trigoneline, chlorogenic acids and sucrose, explaining the sensory differences observed among these coffees. Nevertheless, there are no studies on the relations between different Bourbon genotypes and the production environment and their expression in sensory quality and in chemical composition.

In spite of the high potential of the Bourbon cultivar for production of specialty coffees, there are still questions regarding the existence of a genotype capable of producing high quality coffees regardless of the environment. Nevertheless, there is a belief in the possibility of finding Bourbon genotypes capable of production of specialty coffees in different environments and that its chemical composition may be used as an indicator of this ability.

In this context, this study was performed with the aim of verifying the occurrence of more promising genotypes for the production of specialty coffees in three different environments. In addition, the chemical composition of the grains was studied with a view toward relating these compounds to the genotypes and environments and to the interaction of these factors.

\section{Materials and Methods}

\subsection{Experimental Conditions}

Fourteen arabica coffee (Coffea arabica L.) genotypes were evaluated, including 11 Bourbon genotypes and three commercial cultivars widely planted in Brazil (Table 1). The experiments were carried out in Lavras and Santo Antônio do Amparo county in the south of Minas Gerais State (MG), and in São Sebastião da Grama county in the Mogiana region of the São Paulo State (SP), Brazil.

The Mogiana region, located within the state of São Paulo, has the Atlantic Forest as its predominant biome, with the occurrence of rocky grasslands. The south of the state of Minas Gerais is characterized by a Cerrado (tropical savanna) to Atlantic Forest transition biome, with the occurrence of rocky grasslands. Both regions stand out for large scale production of arabica coffees. The distinct soil and climatic conditions of these important coffee producing regions of Brazil were defined and their main characteristics are shown in Table 2.

Table 1. Arabica coffee genotypes evaluated in the experiment

\begin{tabular}{|c|c|c|}
\hline & Genotype & Origin \\
\hline 1 & Bourbon Amarelo $^{1}$ & Epamig - Machado/MG \\
\hline 2 & Mundo Novo IAC 502/9 & Epamig - Machado/MG \\
\hline 3 & Catuaí Vermelho IAC 144 & Epamig - Machado/MG \\
\hline 4 & Icatu Precoce IAC 3282 & Procafé - Varginha/MG \\
\hline 5 & Bourbon Amarelo ${ }^{2}$ & Procafé - Varginha/MG \\
\hline 6 & Bourbon Amarelo ${ }^{3}$ & Santo Antônio do Amparo/MG \\
\hline 7 & Bourbon Vermelho ${ }^{4}$ & Campos Altos/MG \\
\hline 8 & Bourbon Amarelo LCJ 9 & IAC - Campinas/SP \\
\hline 9 & Bourbon Amarelo ${ }^{5}$ & São Sebastião do Paraíso/MG \\
\hline 10 & Bourbon Amarelo LCJ 10 & Oliveira/MG \\
\hline 11 & Bourbon Amarelo $^{6}$ & Carmo de Minas/MG \\
\hline 12 & Bourbon Amarelo ${ }^{7}$ & Carmos de Minas/MG \\
\hline 13 & Bourbon Trigo ${ }^{8}$ & Alfenas/MG \\
\hline 14 & Bourbon Amarelo ${ }^{9}$ & Santo Antônio do Amparo/MG \\
\hline
\end{tabular}

IAC - Instituto Agronômico.

Epamig - Empresa de Pesquisa Agropecuária de Minas Gerais.

Procafé - Fundação Procafé.

Origin - refers to the institution, city and state (Brazil) where the genotypes were collected to be used in the experiment carried out in Lavras, São Sebastião da Grama and Santo Antônio do Amparo.

1,2,3,4,5,6,7, 8 and 9 - Unidentified Bourbon lineage. 
Table 2. Edaphoclimatic characteristics of each environment

\begin{tabular}{ccccccc}
\hline Environment & Altitude & Soil type & $\begin{array}{c}\text { Average } \\
\text { annual temperature }\end{array}$ & $\begin{array}{c}\text { Average } \\
\text { annual rainfall }\end{array}$ & Latitude & Longitude \\
\hline Lavras & $950 \mathrm{~m}$ & Clayey Oxisol & $20.4^{\circ} \mathrm{C}$ & $1460 \mathrm{~mm}$ & $21^{\circ} 14^{\prime} 43^{\prime \prime} \mathrm{S}$ & $44^{\circ} 59^{\prime} 59^{\prime \prime} \mathrm{W}$ \\
São Sebastião da Grama & $1300 \mathrm{~m}$ & Yellow Oxisol & $20.0^{\circ} \mathrm{C}$ & $1560 \mathrm{~mm}$ & $21^{\circ} 42^{\prime} 38^{\prime \prime} \mathrm{S}$ & $46^{\circ} 49^{\prime} 15^{\prime \prime} \mathrm{W}$ \\
Santo Antônio do Amparo & $1050 \mathrm{~m}$ & Clayey Oxisol & $19.9^{\circ} \mathrm{C}$ & $1700 \mathrm{~mm}$ & $20^{\circ} 91^{\prime} 66^{\prime \prime} \mathrm{S}$ & $44^{\circ} 95^{\prime} 51^{\prime \prime} \mathrm{W}$ \\
\hline
\end{tabular}

\subsection{Experimental Design}

Fourteen arabica coffee (Coffea arabica L.) genotypes were evaluated in three production environments. The three experiments were conducted in a randomized block design (RBD) with three field repetitions for each genotype and ten plants per plot. The three field repetitions of each genotype were collected separately, giving rise to 42 samples for analyses, per environmental site assessed.

\subsection{Harvesting and Processing}

Selective harvesting was performed by hand when the majority of the fruit in each experimental plot reached the ripe cherry stage, followed by hydraulic separation of the fruit by density. The denser ripe fruits were separated from the less dense, over-ripe and floating fruits and the remaining unripe fruits were separated from the lot. A 20 L sample (of the three field repetitions) of cherry fruits were pulped by semi-washed processing procedures (pulped natural) and dried on screens placed over a hard surface until the water content reached $11 \%$ (wet basis).

\subsection{Storage and Processing}

After sixty days, the 42 samples were husked, and defective beans were removed. In the analyses conducted, only $16 / 64,17 / 64$ and 18/64 inch screens beans were used.

\subsection{Sensory Analysis}

Sensory analysis was performed by three professional cuppers accredited by the Coffee Quality Institute, according to the methodology proposed by Lingle (2001). Before each session, the professional cuppers performed calibration. Two random samples were selected to undertake analysis, followed by discussion of all the attributes and final sensory score. After the calibration session, the samples were recodified and analyzed with the other samples. In this evaluation, scores on a scale of zero to ten were awarded for the following attributes: aroma, uniformity, clean cup, sweetness, flavor, acidity, body, aftertaste, balance and overall taste. Each growing environment was evaluated separately, and the results of the sensory evaluation were registered according to the SCAA classification scale (Lingle, 2001). For each evaluation, five cups of coffee that were representative of each genotype were tasted, undertaking a sensory analysis session for each one of the three repetitions.

In addition to the final score obtained in sensory evaluation, the attributes of aroma, acidity, body, balance and flavor were statistically analyzed, considering that they are the main attributes responsible for distinguishing different sensory profiles of coffee.

\subsection{Chemical Analysis}

The extraction and quantification of trigonelline, caffeine and chlorogenic acids were made in duplicate for each of the three field repetitions (42 samples). For the simultaneous extraction and quantification, $100 \mathrm{mg}$ of green coffee beans were mixed with $5 \mathrm{~mL}$ of $70 \%$ methanol (HPLC) prepared in ultra pure water $(18.2 \mathrm{M} \Omega . \mathrm{cm}$ ) obtained from a Milli-Q (Millipore) device and kept in a water bath at $60^{\circ} \mathrm{C}$ for one hour. The tubes were agitated at ten-minute intervals. After the extraction of the compounds, the samples were centrifuged at $12.000 \mathrm{rpm}$ in $1.5 \mathrm{~mL}$ Eppendorf tubes. The supernatant was diluted in ultra pure water at a ratio of 1:10 (v/v). After filtration through a $0.22 \mu \mathrm{m}$ membrane, $20 \mu \mathrm{L}$ of each sample was analyzed using a $\mathrm{C}_{18}$ Shim-pack column (CLC-ODS (M)- 25X4.6 mm, Shimadzu, Japan) with a guard column (CLC G-ODS 4X1 mm Shimadzu, Japan). Isocratic elution was performed with a mobile phase composed of methanol: acetic acid: water (30: 0.5: 69.5, v/v/v) at $1 \mathrm{~mL} \mathrm{~min}^{-1}$ at $30^{\circ} \mathrm{C}$. The concentrations of the compounds caffeine, trigonelline and 5-caffeoylquinic acid (5-CQA) in the samples were determined by comparing the areas with the areas of the standard (Sigma-Aldrich, US) solutions prepared at known concentrations. The results were expressed as percentages of dry matter $(\% \mathrm{dm})$. Concentrations of caffeine, trigonelline and 5- caffeoylquinic acid (5-CQA) were determined simultaneously using HPLC.

\subsection{Statistical Analysis}

To determine whether it was necessary to analyze the chemical results in combination with the sensory results, hierarchical cluster analysis by variables was used. 
The trigonelline, caffeine, 5-CQA content and the final sensory score were evaluated using analysis of variance (ANOVA). When significant differences in the F test were detected, the Scott-Knott test was applied, using the SISVAR ${ }^{\circledR}$ program (Ferreira, 2011).

\subsection{Principal Component Analysis}

To study the correlations between the sensory attributes of aroma, flavor, acidity, body, and balance and the final score, statistical analyses of these correlations was conducted using the Biplots technique and principal component analysis (PCA) (Jolliffe, 2002). The biplots were developed to identify which sensory attributes are correlated with the genotypes. The estimated coefficients for each component were obtained through a correlation matrix of sensory attribute groups inherent to each environment. Data for each genotype were represented as the mean of scores calculated from three repetitions.

\section{Results and Discussion}

Figure 1 refers to the dendrograms for the similarity of the sensory attributes (aroma, flavor, balance, acidity, body and final score) with the chemical analysis (trigonelline, caffeine and 5-CQA), with reference to the mean data of all the genotypes in each environment. In the three environments examined, the sensory attributes were grouped separately from the chemical properties, which justifies the separate analyses of sensory and chemical results for this work.
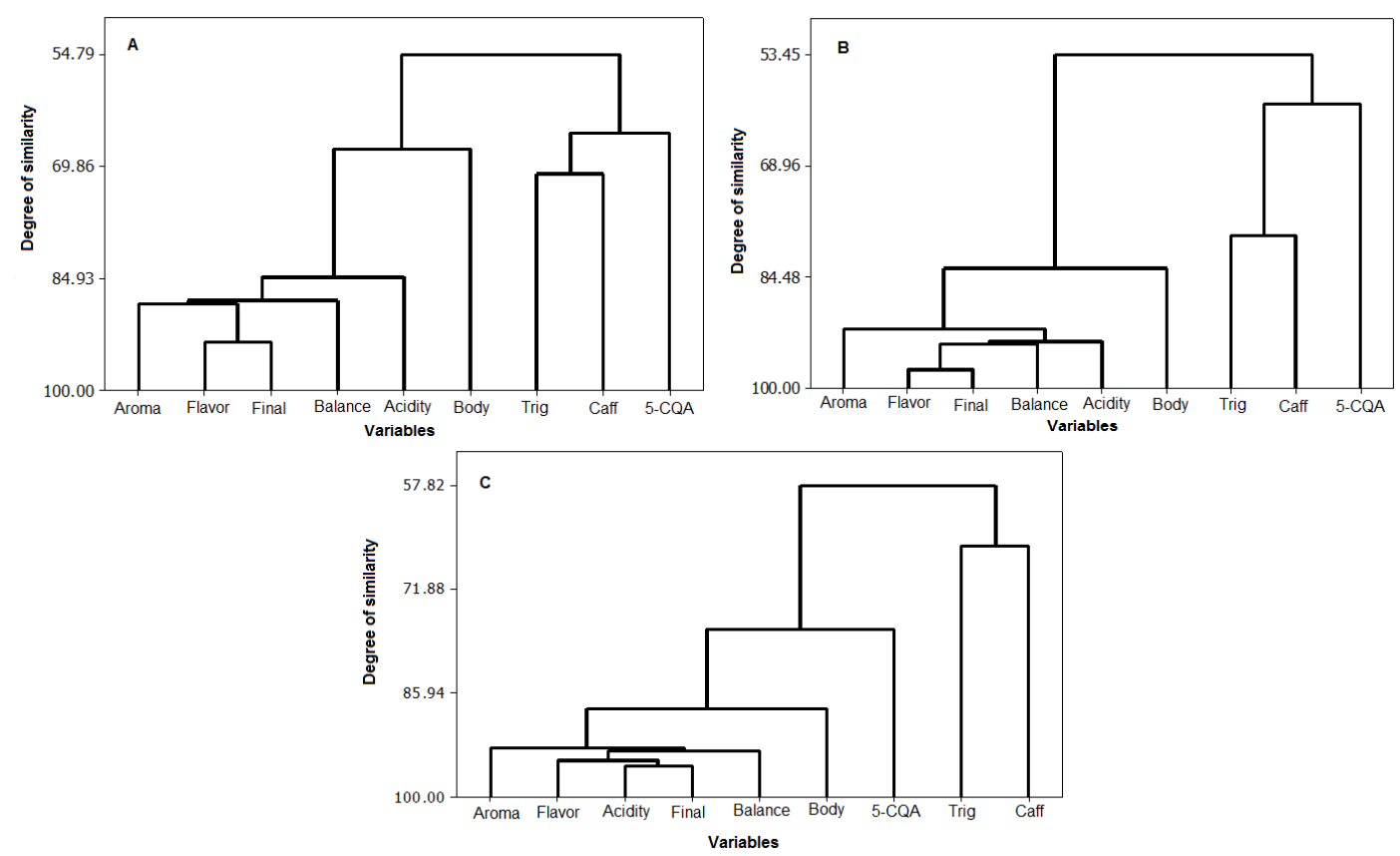

Figure 1. Dendrograms for the similarity between chemical analysis and sensory attributes from the following environments: Lavras (A), São Sebastião da Grama (B) and Santo Antônio do Amparo (C). Final = Final score, Trig $=$ Trigonelline, Caff $=$ Caffeine

It was observed that among the sensory attributes, body showed the least similarity compared to the other sensory attributes, especially in Lavras (Figure 1), which showed a degree of similarity of less than 69.86\%. The fact that this attribute stands out from others in the three environments studied, with distinct similarities in each environment, shows the influence of the environment on the sensory characteristics.

\subsection{Chemical Analysis}

The chromatogram of standard solutions of trigonelline, 5-CQA and caffeine with their retention times and the chromatogram of an extract of green coffee beans are shown in Figure 2. 

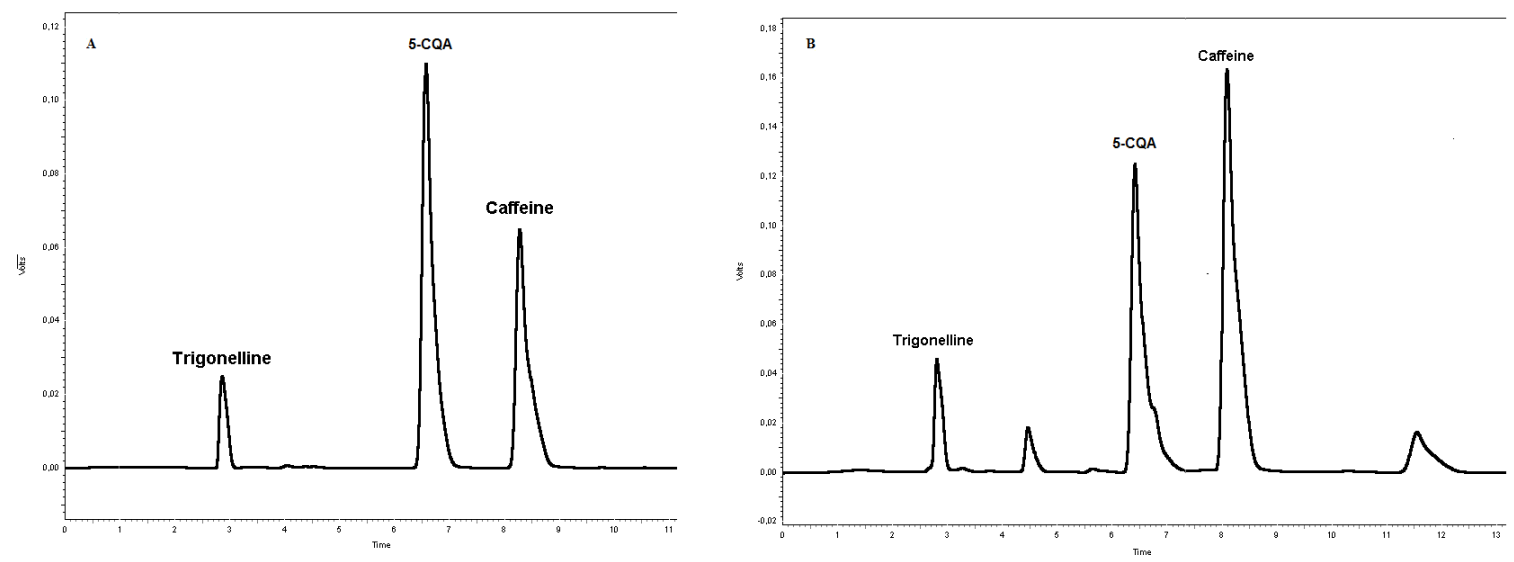

Figure 2. Chromatogram of standard solutions of trigonelline ( $2.9 \mathrm{~min}$.), 5-CQA $(\sim 6.7 \mathrm{~min}$.) and caffeine $(\sim 8.4$ min.) (A) and chromatogram of a sample of green coffee beans (B )

The genotype $\mathrm{x}$ environment interaction was significant for trigonelline and caffeine but was not significant for 5-CQA (Table 3). The mean trigonelline and caffeine contents $(\% \mathrm{dm})$ resulting from the genotype $\mathrm{x}$ environment interaction and the mean 5-CQA content $(\% \mathrm{dm})$ for the fourteen genotypes regardless of environment are shown in Table 3 .

Table 3. Mean levels of trigonelline and caffeine from genotypes in specific environments, and mean values of 5-CQA (\%dm) for all genotypes

\begin{tabular}{|c|c|c|c|c|c|c|c|}
\hline \multirow{3}{*}{ Genotypes } & \multicolumn{3}{|c|}{ Trigonelline (\%dm) } & \multicolumn{3}{|c|}{ Caffeine (\%dm) } & \multirow{3}{*}{ 5-CQA $(\% \mathrm{dm})^{3}$} \\
\hline & \multicolumn{3}{|c|}{ Environments } & \multicolumn{3}{|c|}{ Environments } & \\
\hline & Lavras & $\mathrm{SSG}^{1}$ & $\mathrm{SAA}^{2}$ & Lavras & $\mathrm{SSG}^{l}$ & $\mathrm{SAA}^{2}$ & \\
\hline 1 & $0.96 \pm 0.03 \mathrm{aA}$ & $1.10 \pm 0.10 \mathrm{bB}$ & $1.09 \pm 0.01 \mathrm{cB}$ & $1.10 \pm 0.06 \mathrm{aA}$ & $1.23 \pm 0.09 \mathrm{aB}$ & $1.20 \pm 0.03 \mathrm{aB}$ & $6.30 \pm 0.10 \mathrm{~b}$ \\
\hline 2 & $0.92 \pm 0.04 \mathrm{aA}$ & $1.05 \pm 0.03 \mathrm{bB}$ & $1.06 \pm 0.05 \mathrm{cB}$ & $1.10 \pm 0.07 \mathrm{aA}$ & $1.23 \pm 0.02 \mathrm{aB}$ & $1.23 \pm 0.06 \mathrm{aB}$ & $5.70 \pm 0.20 \mathrm{a}$ \\
\hline 3 & $0.92 \pm 0.03 \mathrm{aA}$ & $1.12 \pm 0.02 \mathrm{cB}$ & $1.07 \pm 0.06 \mathrm{cB}$ & $1.19 \pm 0.04 \mathrm{aA}$ & $1.37 \pm 0.07 \mathrm{bB}$ & $1.20 \pm 0.05 \mathrm{aA}$ & $6.10 \pm 0.10 \mathrm{~b}$ \\
\hline 4 & $0.99 \pm 0.06 \mathrm{aA}$ & $1.08 \pm 0.02 \mathrm{cB}$ & $1.11 \pm 0.03 \mathrm{cB}$ & $1.29 \pm 0.05 \mathrm{bB}$ & $1.39 \pm 0.01 \mathrm{bC}$ & $1.18 \pm 0.06 \mathrm{aA}$ & $5.88 \pm 0.08 \mathrm{a}$ \\
\hline 5 & $0.93 \pm 0.08 \mathrm{aA}$ & $1.06 \pm 0.01 \mathrm{bB}$ & $0.99 \pm 0.05 \mathrm{bA}$ & $1.10 \pm 0.07 \mathrm{aA}$ & $1.26 \pm 0.03 \mathrm{aB}$ & $1.16 \pm 0.04 \mathrm{aA}$ & $6.10 \pm 0.10 \mathrm{~b}$ \\
\hline 6 & $0.92 \pm 0.04 \mathrm{aA}$ & $1.08 \pm 0.04 \mathrm{cB}$ & $1.02 \pm 0.05 \mathrm{bB}$ & $1.14 \pm 0.04 \mathrm{aA}$ & $1.19 \pm 0.05 \mathrm{aA}$ & $1.14 \pm 0.03 \mathrm{aA}$ & $6.30 \pm 0.10 \mathrm{~b}$ \\
\hline 7 & $0.95 \pm 0.06 \mathrm{aA}$ & $1.03 \pm 0.01 \mathrm{bB}$ & $1.04 \pm 0.08 \mathrm{cB}$ & $1.16 \pm 0.08 \mathrm{aA}$ & $1.24 \pm 0.05 \mathrm{aA}$ & $1.18 \pm 0.07 \mathrm{aA}$ & $5.74 \pm 0.07 \mathrm{a}$ \\
\hline 8 & $0.89 \pm 0.03 \mathrm{aA}$ & $1.08 \pm 0.05 \mathrm{cC}$ & $0.99 \pm 0.05 \mathrm{bB}$ & $1.12 \pm 0.03 \mathrm{aA}$ & $1.30 \pm 0.10 \mathrm{aB}$ & $1.07 \pm 0.08 \mathrm{aA}$ & $5.92 \pm 0.04 \mathrm{a}$ \\
\hline 9 & $0.91 \pm 0.05 \mathrm{aA}$ & $1.04 \pm 0.03 \mathrm{bB}$ & $1.00 \pm 0.03 \mathrm{bB}$ & $1.09 \pm 0.04 \mathrm{aA}$ & $1.22 \pm 0.04 \mathrm{aB}$ & $1.14 \pm 0.06 \mathrm{aA}$ & $6.01 \pm 0.06 \mathrm{~b}$ \\
\hline 10 & $0.96 \pm 0.03 \mathrm{aA}$ & $1.19 \pm 0.07 \mathrm{~dB}$ & $1.02 \pm 0.05 \mathrm{bA}$ & $1.10 \pm 0.05 \mathrm{aA}$ & $1.30 \pm 0.10 \mathrm{aB}$ & $1.10 \pm 0.10 \mathrm{aA}$ & $5.79 \pm 0.04 \mathrm{a}$ \\
\hline 11 & $0.89 \pm 0.03 \mathrm{aA}$ & $1.00 \pm 0.01 \mathrm{bB}$ & $1.06 \pm 0.10 \mathrm{cB}$ & $1.12 \pm 0.06 \mathrm{aA}$ & $1.18 \pm 0.06 \mathrm{aA}$ & $1.16 \pm 0.05 \mathrm{aA}$ & $6.10 \pm 0.20 \mathrm{~b}$ \\
\hline 12 & $0.88 \pm 0.01 \mathrm{aA}$ & $1.01 \pm 0.01 \mathrm{bB}$ & $1.08 \pm 0.07 \mathrm{cC}$ & $1.16 \pm 0.01 \mathrm{aA}$ & $1.19 \pm 0.06 \mathrm{aA}$ & $1.10 \pm 0.10 \mathrm{aA}$ & $6.00 \pm 0.20 \mathrm{a}$ \\
\hline 13 & $0.83 \pm 0.03 \mathrm{aA}$ & $0.92 \pm 0.03 \mathrm{aB}$ & $0.91 \pm 0.03 \mathrm{aB}$ & $1.18 \pm 0.04 \mathrm{aA}$ & $1.22 \pm 0.02 \mathrm{aA}$ & $1.15 \pm 0.02 \mathrm{aA}$ & $5.56 \pm 0.03 a$ \\
\hline 14 & $0.91 \pm 0.01 \mathrm{aA}$ & $1.13 \pm 0.01 \mathrm{cC}$ & $1.03 \pm 0.04 \mathrm{cB}$ & $1.15 \pm 0.05 \mathrm{aA}$ & $1.30 \pm 0.02 \mathrm{bB}$ & $1.18 \pm 0.05 \mathrm{aA}$ & $5.90 \pm 0.20 \mathrm{a}$ \\
\hline Mean & $0.92 \mathrm{~A}$ & $1.06 \mathrm{C}$ & $1.03 \mathrm{~B}$ & $1.14 \mathrm{~A}$ & $1.25 \mathrm{~B}$ & $1.15 \mathrm{~A}$ & - \\
\hline
\end{tabular}

Mean \pm standard deviation of three field repetitions. Means followed by the same small letter in the columns and the same capital letter in the lines are not significantly different when using the Scott-Knott test $(p<0.05) .{ }^{1} \mathrm{SSG}=$ São Sebastião da Grama; ${ }^{2}$ SAA $=$ Santo Antônio do Amparo. ${ }^{3}$ genotype x environment interaction was not significant for 5-CQA. 
It can be observed after analyzing the genotypes in each environment (Table 3) that Bourbon Trigo had smaller mean trigonelline values and differed $(p \leq 0.05)$ from the other genotypes from São Sebastião da Grama and Santo Antonio do Amparo. Genotypes planted in Lavras (altitude $950 \mathrm{~m}$ ) exhibited smaller mean trigonelline values compared to those occurring in the other environments. Significant differences were found between the overall means of trigonelline levels in the three environments. The highest values appeared in genotypes planted in São Sebastião da Grama (altitude 1300 m). In this study, genotypes from São Sebastião da Grama had the best final sensory score (Table 4). These results confirm those of Farah et al. (2006) who reported that higher trigonelline levels produce better beverage quality coffees.

The trigonelline content in coffee beans varies appreciably among the different species of Coffea (Campa et al., 2004). However, the reduced differences of this alkaloid among the arabica genotypes observed within the same locality suggest that trigonelline content is not a good indicator for differentiation of genotypes. The levels of trigonelline shown in Table 3 confirm those recorded in the literature where the trigonelline levels in C. arabica were shown to vary from 0.79 to $1.77 \%$ (dm) (Stennert \& Maier, 1994).

The highest mean values of caffeine content (Table 3) were found in the genotypes planted in São Sebastião da Grama (which differed statistically from the other environments). However, the effect described is only significant for genotypes 3, 4, 5, 8, 9, 10 and 14, not for all the genotypes under analysis. São Sebastião da Grama shows nine genotypes with lower caffeine levels than the highest caffeine level found in Lavras. Therefore, it is not possible to relate higher expression of caffeine to genotypes cultivated in São Sebastião da Grama.

Although caffeine content was not found to have a direct effect on beverage quality, Franca et al. (2005) and Farah et al. (2006) found higher levels of caffeine in samples of high quality arabica coffee beverages when compared to other samples. In the present study, a relationship between caffeine content and beverage quality was not found under the conditions described; thus, caffeine was not shown to be a good discriminator of genotype $\mathrm{x}$ environment interaction.

Table 4. Mean content of 5-CQA and final sensory scores for the three environments

\begin{tabular}{lll}
\hline Environment & 5-CQA (\%dm) & Final score \\
\hline Lavras & $5.81 \mathrm{a}$ & $80.34 \mathrm{a}$ \\
São Sebastião da Grama & $5.85 \mathrm{a}$ & $80.54 \mathrm{a}$ \\
Santo Antônio do Amparo & $6.16 \mathrm{~b}$ & $79.79 \mathrm{a}$
\end{tabular}

Means followed by the same letter in the columns are not significantly different using the Scott-Knott test $(p<0.05)$.

The genotype $\mathrm{x}$ environment interaction was not significant for the 5-CQA concentration. A significant difference $(p \leq 0.05)$ was observed for the genotype variable, regardless of the environment, and for the environment variable, regardless of the genotype studied (Table 4).

The Santo Antônio do Amparo environment had the highest mean value of 5-CQA (Table 4) and the lowest mean sensory final score (Table 4). SCAA sensory evaluation of specialty coffees proposes that coffees with a final score from 75 to 79 points are classified as commodity coffees, and those with a final score from 80 to 84 points are considered very good and can be classified as specialty coffees (Lingle, 2001). Taking the SCAA scale into consideration, the present study shows that although the coffees produced in Santo Antônio do Amparo are of good quality, they are not specialty coffees. This environment was the only one that scored lower than 80 points. Although there was no statistical difference (significance level of 0.05 ) among the environments for final score, it is possible to find different sensory profiles. Avelino et al. (2005) attributed the accumulation of chlorogenic acids to higher altitudes. Another study by Guyot et al. (1996), reports that the stability of chlorogenic acids is related to the altitude. In the present study, higher 5-CQA contents were found at intermediate altitudes. According to Joet et al. (2010), such discrepancies are likely due to the effects of other climatic factors in the different environments.

According to Perrone, Farah, Donangelo, Paulis and Martin (2008), chlorogenic acids are important for flavor during roasting and have a strong effect on beverage astringency. Even at low concentrations, the impact of chlorogenic acids on quality can be significant, and lower chlorogenic acid contents correlate with better beverage quality. Assuming that the criterion for the selection of mature fruit was applied uniformly in the three 
environments, it appears that environmental variables in each growing area were responsible for the higher mean levels of 5-CQA, which consequently affect the final quality of the beverage.

It was not possible to show any discrimination of the genotype $\mathrm{x}$ environment interaction using the chemical compounds studied, whether they were analyzed together or individually; however, the content of trigonelline allowed discrimination among the three environments studied.

\subsection{Sensory Analysis}

Principal component analysis was applied to verify which genotypes could be organized into groups and which sensory attributes contributed to the formation of those groups.
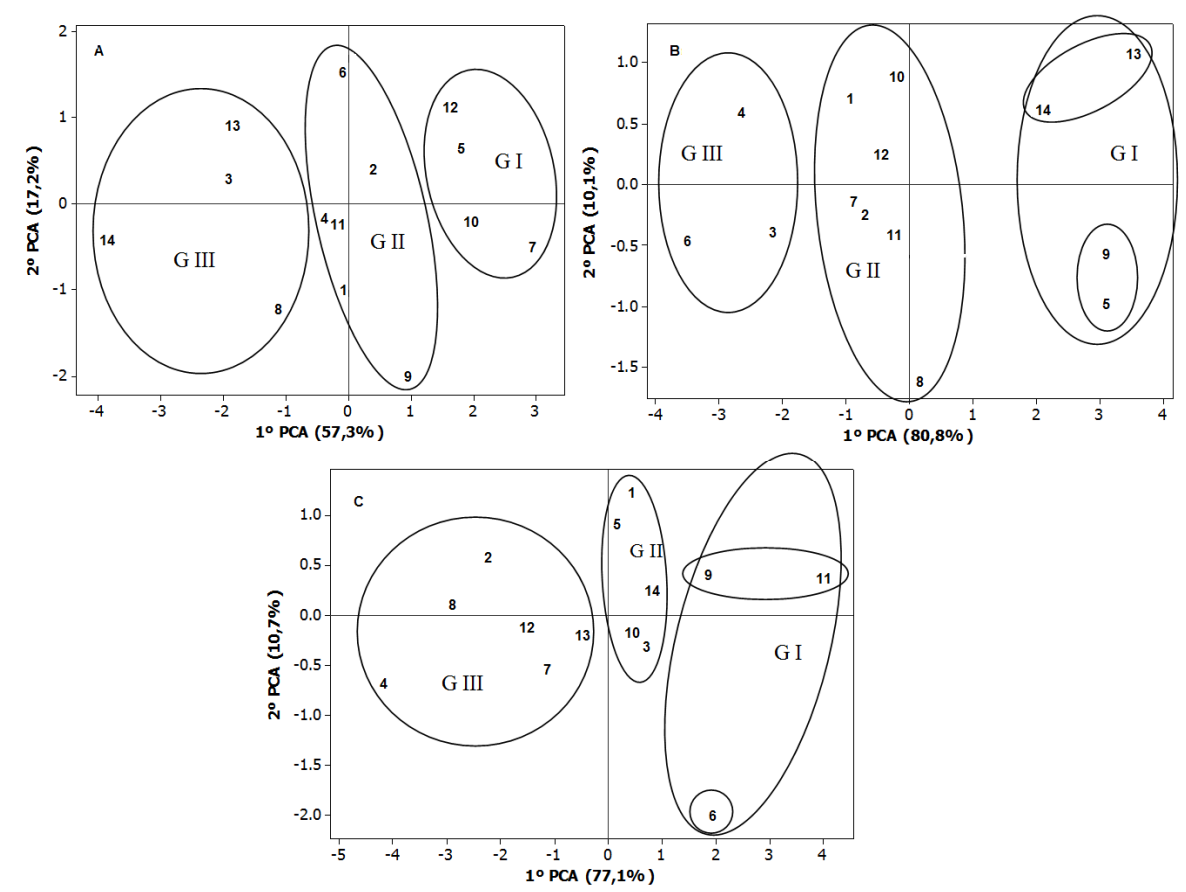

Figure 3. Scores of the first principal components from the following environments: Lavras (A), São Sebastião da Grama (B) and Santo Antônio do Amparo (C). GI = Group I, GII = Group II, GIII = Group III 

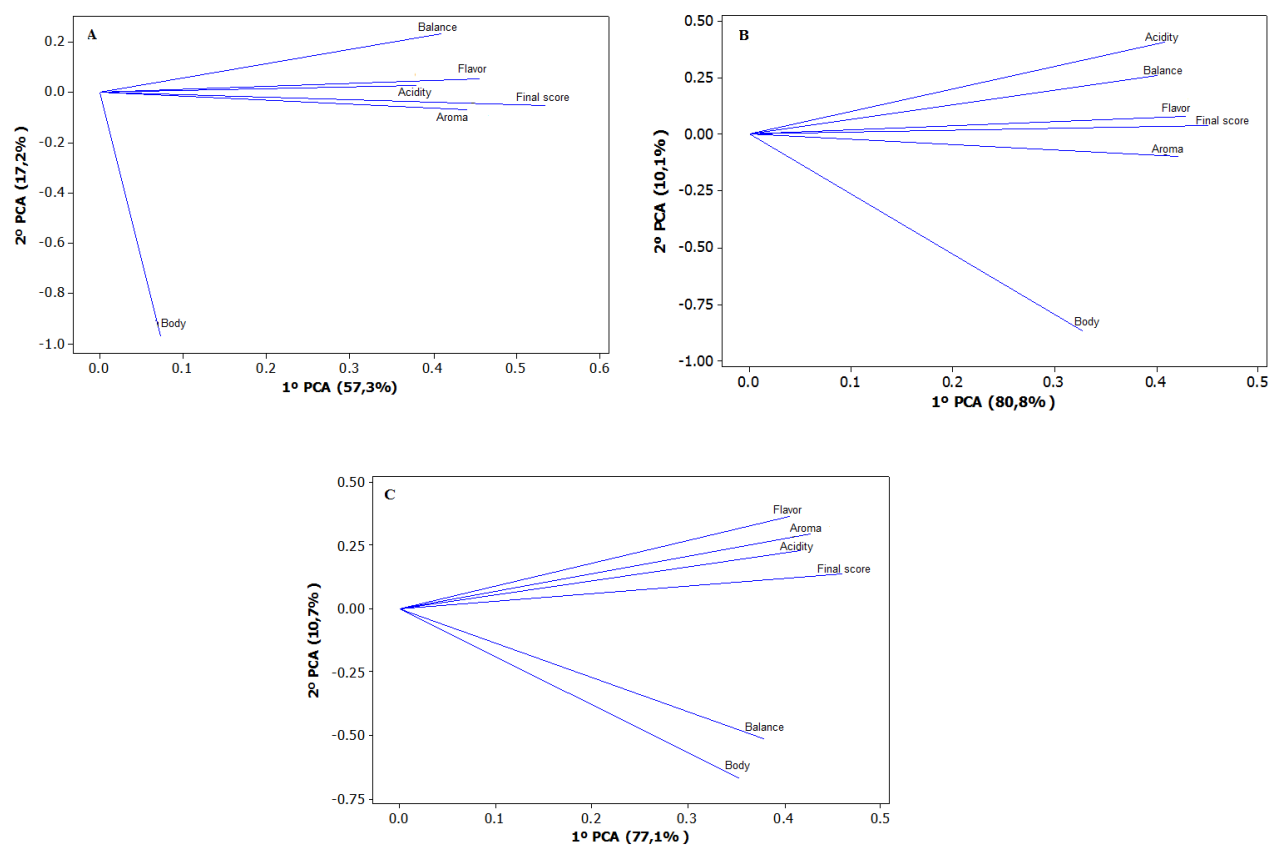

Figure 4. Biplot charts of the sensory attributes from the following environments: Lavras (A), São Sebastião da Grama (B) and Santo Antônio do Amparo (C)

Figure 3 shows the score plots of the samples from Lavras (A), São Sebastião da Grama (B) and Santo Antônio do Amparo (C) represented in the space defined by the first two principal components. The biplots of the loading of the sensory attributes and final score data in the first two principal components are shown in Figure 4. Genotypes with similar sensory attributes and final scores were grouped close together. The loading plots indicate the most important attributes for each grouping. The first two principal components account for $74.5 \%, 90.9 \%$ and $87.8 \%$ of the total system variability, in regard to the Lavras, São Sebastião da Grama and Santo Antônio do Amparo environments, respectively."

As a function of their positive or negative correlation to all attributes, the first principal component allowed the separation of genotypes into three possible groups (Figure 3). In Figure 3, genotypes that generally received higher sensory evaluation scores are on the right, and those with lower scores are on the left of the score plot (Table 5). It is possible to form an intermediate group (GII), thus resulting in the formation of three groups with distinct sensory characteristics.

In Lavras, the separation of genotypes is readily observed in the allocation of genotypes 14 (Bourbon Amarelo) and 7 (Bourbon Vermelho) (Figure 3A), which received the lowest and highest final scores in PC1, respectively. The group with the best beverage quality, composed of genotypes 7, 10, 12 and 5, presented the highest positive loadings for the attributes of balance, flavor, acidity, aroma and final score (Figure 4A). Analysis of the loadings in PC2 identified genotype 9 as having the best body.

The data in Table 5 show that Group I (Lavras) had a final score of about 81 points and stands out above GII and GIII. Although values between the groups do not differ statistically, they may have different sensory profiles relevant for commercial purposes, according to the SCAA (Lingle, 2001).

Group I genotypes cultivated in Lavras show great potential for the production of specialty coffees. Group I is composed of only Bourbon genotypes, which show great promise in the production of superior quality coffees (Table 5). Working with the chemical and sensory characteristics of 21 cultivars of arabica coffee, Pereira, Chalfoun, Carvalho and Savian (2010) identified Bourbon Amarelo as the cultivar with potential to produce specialty coffee when processed using the pulped natural process. 
Table 5. Mean final scores from the growing areas of Lavras, São Sebastião da Grama and Santo Antônio do Amparo, grouped according to principal component analysis.

\begin{tabular}{|c|c|c|c|c|c|c|c|c|c|c|}
\hline \multicolumn{3}{|l|}{ Lavras } & \multicolumn{4}{|c|}{$\mathrm{SSG}^{l}$} & \multicolumn{4}{|c|}{$\mathrm{SSA}^{2}$} \\
\hline & $\mathrm{G}^{3}$ & $\mathrm{FS}^{4}$ & & & $\mathrm{G}^{3}$ & $\mathrm{FS}^{4}$ & & & $\mathrm{G}^{3}$ & $\mathrm{FS}^{4}$ \\
\hline \multirow{4}{*}{ Group I } & 7 & $81.38 \mathrm{a}$ & \multirow{4}{*}{ Group I } & \multirow{2}{*}{$\operatorname{Subg}^{e} I$} & 13 & $82.67 b$ & \multirow{4}{*}{ Group I } & \multirow{2}{*}{$\operatorname{Subg}^{e} \mathrm{I}$} & 11 & $81.71 \mathrm{a}$ \\
\hline & 10 & $81.17 \mathrm{a}$ & & & 14 & $81.75 b$ & & & 9 & $80.75 a$ \\
\hline & 12 & $81.00 \mathrm{a}$ & & \multirow{2}{*}{$\operatorname{Subg}^{e}$ II } & 9 & $82.46 \mathrm{~b}$ & & \multirow{2}{*}{$\operatorname{Subg}^{e}$ II } & 6 & $80.38 \mathrm{a}$ \\
\hline & 5 & $80.80 \mathrm{a}$ & & & 5 & $82.01 \mathrm{~b}$ & & & - & - \\
\hline \multirow{7}{*}{ Group II } & 9 & $80.75 a$ & \multirow{7}{*}{ Group II } & & 11 & $80.54 a$ & \multirow{7}{*}{ Group II } & & 14 & $80.13 a$ \\
\hline & 2 & $80.54 \mathrm{a}$ & & & 10 & $80.50 \mathrm{a}$ & & & 3 & $80.09 \mathrm{a}$ \\
\hline & 1 & $80.33 a$ & & & 8 & $80.46 a$ & & & 1 & $80.05 \mathrm{a}$ \\
\hline & 4 & $80.30 \mathrm{a}$ & & & 2 & $80.13 a$ & & & 5 & $80.00 \mathrm{a}$ \\
\hline & 11 & $80.29 a$ & & & 12 & $80.13 a$ & & & 10 & $80.00 \mathrm{a}$ \\
\hline & 6 & $80.21 \mathrm{a}$ & & & 1 & $80.04 \mathrm{a}$ & & & - & - \\
\hline & - & - & & & 7 & $80.04 \mathrm{a}$ & & & - & - \\
\hline \multirow{6}{*}{ Group III } & 8 & $79.96 a$ & \multirow{6}{*}{ Group III } & & 3 & $79.54 a$ & \multirow{6}{*}{ Group III } & & 13 & $79.67 \mathrm{a}$ \\
\hline & 3 & $79.63 \mathrm{a}$ & & & 4 & $78.69 \mathrm{a}$ & & & 7 & $79.33 a$ \\
\hline & 13 & $79.54 \mathrm{a}$ & & & 6 & $78.63 a$ & & & 12 & $79.19 \mathrm{a}$ \\
\hline & 14 & $78.96 \mathrm{a}$ & & & - & - & & & 2 & $79.17 \mathrm{a}$ \\
\hline & - & - & & & - & - & & & 8 & $78.63 a$ \\
\hline & - & - & & & - & - & & & 4 & $78.00 \mathrm{a}$ \\
\hline
\end{tabular}

Measurements followed by the same letter in the columns are not significantly different using the Scott-Knott test $(p<0.05) .{ }^{I} \mathrm{SSG}=$ São Sebastião da Grama; ${ }^{2} \mathrm{SAA}=$ Santo Antônio do Amparo; ${ }^{3} \mathrm{G}=$ Genotype; ${ }^{4} \mathrm{FS}=$ Final Score; $e$ Subg $=$ subgroup.

The cultivars Mundo Novo IAC 502/9 (2), Catuai Vermelho IAC 144 (3), and Icatu Precoce IAC 3282 (4) did not differ significantly from the Bourbon genotypes. However, the data in Table 5 (Lavras) show that the Catuai Vermelho IAC 144 cultivar (3) did not receive the minimum score necessary to be included in the specialty coffee category. In this environment, the similarity between the Mundo Novo IAC 502/9 (2) and Icatu Precoce IAC 3282 (4) cultivars agrees with reports found in the literature. According to Fazuoli (1986), the beverage quality of the Icatu cultivars was similar to that of the best selections of Mundo Novo.

In São Sebastião da Grama, the second principal component was responsible for the differentiation between genotypes 13 and 14 and genotypes 9 and 5 that subdivide Group I (Figure 3B), mainly due to the attributes of body and acidity and balance (Figure 4B). Group I genotypes stood out in the sensorial category, receiving the highest final score, reaching close to or above 82 points (Table 5).

Group I genotypes in the São Sebastião da Grama and Lavras environments are all Bourbons. Notably, the genotypes that were more promising from the sensory point of view were encountered in each environment, attesting to the potential for Bourbon genotypes to produce coffees of superior quality.

The fact that the best genotypes in a given location were different from the best genotypes in another confirms the effect of environment on beverage quality.

In general, the best G1 coffees from São Sebastião da Grama obtained higher final scores than the best coffees in the other environments studied. According to Martins, Camargo and Bataglia (2005), the majority of coffees produced in this region, known as Paulista Mogiana, are classified as "soft beverages" because of the area's mild temperatures and low rainfall at the time of maturity and harvest.

Although the Group II coffees from São Sebastião da Grama also received final scores above 80 points, they were statistically different from coffees belonging to Group I (Table 5). Although classified as specialty coffees, they 
were inferior in quality compared to the coffees in Group I. In this production environment, the Catuai Vermelho IAC 144 cultivar (3), along with other Group III genotypes, did not show potential for the production of specialty coffees (Table 5).

It is observed that genotypes 13 and 14 (subgroup I) possess great acidity, and balance, whereas genotypes 5 and 9 (subgroup II) have better body (Figure 3B - 4B). These results are interesting because they reveal the interaction of the unique attributes, which can result in superior quality coffees that possess unique characteristics.

In Santo Antônio do Amparo, the second principal component made it possible to divide Group I into two subgroups (Figure 3C), mainly due to the body and balance attributes, and secondly to flavor, aroma and acidity (Figure 4C). This differentiation is apparent through vector analysis associated with each attribute, as shown in Figure 4C. Genotypes 11 and 9 presented better flavor, aroma, and acidity than genotype 6, which had greater balance and body (Figure 4C).

Notably, although the genotypes in subgroups I and II had different sensory characteristics, they all received final scores above 80 points. These results demonstrate the need to individually evaluate each sensorial characteristic so that different characteristics between genotypes with the same final scores can be determined. Differences can be detected with standardized methods, such as those adopted by the SCAA for the evaluation of specialty coffees. This methodology utilizes procedures that minimize subjectivity, including objective evaluations of the presence or absence of sweetness and defects, and awards points for diverse sensory attributes.

In São Sebastião da Grama, the Group III genotype 6 (Table 5) exhibited the lowest sensory final score. In Santo Antônio do Amparo, the same genotype obtained one of the highest sensory final scores as a part of Group I (Table 5), which can be explained by the genotype $\mathrm{x}$ environment interaction.

Although it was not possible to identify a single genotype recommended for the production of specialty coffees for all three environments studied, it was possible to identify a specific group of promising Bourbon genotypes for the production of specialty coffees for each environment, represented by Group I genotypes shown in Figure 3A, 3B and $3 \mathrm{C}$.

Because higher altitudes have been shown to produce better quality coffees (Silva, Pereira, Borém, \& Silva, 2006), it is expected that the São Sebastião da Grama environment (altitude $1300 \mathrm{~m}$ ) offers better conditions for certain genotypes (GI) to express their qualities when compared to the other environments; in fact, the final scores obtained are higher for genotypes of GI. Barbosa et al. (2012), studying coffee quality and its interactions with environmental factors, report that the higher the altitude, the higher the sensory score. The Bourbon Amarelo (5) and Bourbon Amarelo (9) genotypes stand out by producing high beverage quality in a favorable environment (São Sebastião da Grama). However, when grown in environments that are considered less favorable for quality, such as Lavras and Santo Antônio do Amparo, these genotypes were still able to produce high beverage quality. The Bourbon Trigo genotype (13), however, produced a higher final sensory score in the São Sebastião da Grama environment but did not exhibit such high scores in the two other less favorable environments, justifying future studies of these genotypes.

\section{Conclusions}

Bourbon genotypes show the greatest potential for production of specialty coffees in all environments.

The genotypes belonging to group I are the most promising for production of specialty coffees in each one of the environments studied.

Trigonelline content allowed discrimination of environments.

\section{References}

Avelino, J., Barboza, B., Araya, J. C., Fonseca, C., Davrieux, F., \& Guyot, B. (2005). Effects of slope exposure, altitude and yield on coffee quality in two altitude terroirs of Costa Rica, Orosi and Santa Maria de Dota. Journal of the Science of Food and Agriculture, 85, 1869-1876. http://dx.doi.org/10.1002/jsfa.2188

Barbosa, J. N., Borem, F. M., Cirillo, M. A., Malta, M. R., Alvarenga, A. A., \& Alves, H. M. R. (2012). Coffee Quality and Its Interactions with Environmental Factors in Minas Gerais, Brazil. Journal of Agricultural Science, 4(5), 181-190. http://dx.doi.org/10.5539/jas.v4n5p181

Bertrand, B., Villarreal, D., Laffargue, A,; Posada, H., Lashermes, P., \& Dussert, S. (2008). Comparison of the effectiveness of fatty acids, chlorogenic acids, and elements for the chemometric discrimination of coffee (Coffea arabica L.) varieties and growing origins. Journal of Agricultural and Food Chemistry, 56, 2273-2280. http://dx.doi.org/10.1021/jf073314f 
Bicchi, C. P., Binello, A. E., Pellegrino, G. M., \& VAnni, A. C. (1995). Characterization of green and roasted coffees through the chlorogenic acid fraction by HPLCUV and principal component analysis. Journal of Agricultural and Food Chemistry, 43, 1549-1555. http://dx.doi.org/10.1021/jf00054a025

Camargo, M. B. P. De. (2010). The impact of climatic variability and climate change on arabic coffee crop in Brazil. Bragantia, 69, 239-247. http://dx.doi.org/10.1590/S0006-87052010000100030

Campa, C., Ballester, J. F., Doulbeau, S., Dussert, S., Hamon, S., \& Noirot, M. (2004). Trigonelline and sucrose $\begin{array}{lllll}\text { diversity in wild Coffea species. Food Chemistry, } 88, & 39-43 .\end{array}$ http://dx.doi.org/10.1016/j.foodchem.2004.01.020

Casal, S., Oliveira, B., \& Ferreira, M. A. (2000). HPLC/diode-array applied to thermal degradation of trigonelline, nicotinic acid and caffeine in coffee. Food Chemistry, 68, 481-485. http://dx.doi.org/10.1016/S0308-8146(99)00228-9

Farah, A., Monteiro, M. C., Calado, V., Franca, A. S., \& Trugo, L. C. (2006). Correlation between cup quality and chemical attributes of Brazilian coffee. Food Chemistry, 98, 373-380. http://dx.doi.org/10.1016/j.foodchem.2005.07.032

Fazuoli, C. (1986). Genética e melhoramento do cafeeiro. In A. B. RENA et al. (Eds.), Cultura do cafeeiro: fatores que afetam a produtividade. Piracicaba: Potafos.

Fazuoli, L. C., Guerreiro Filho, O., Silvarolla, M. B., Medina Filho, H. P., \& Carvalho, A. (2005). Selections of Mundo Novo, Bourbon Amarelo and Bourbon Vermelho cultivars of Coffea arabica in Campinas. Bragantia, 64, 533-546. http://dx.doi.org/10.1590/S0006-87052005000400003

Ferreira, D. F. (2011). Sisvar: a computer statistical analysis system. Ciência e. Agrotecnologia, 35, 1039-1042. http://dx.doi.org/10.1590/S1413-70542011000600001

Franca, A. S., Mendonça, J. C. F., \& Oliveira, S. D. (2005). Composition of green and roasted coffees of different cup qualities. LWT - Food Science and Technology, 38, 709-715. http://dx.doi.org/10.1016/j.lwt.2004.08.014

Guyot, B., Gueule, D., Manez, J. C., Perriot, J. J., Giron, J., \& Villain, L. (1996). Influence de l'altitude et de l'ombrage sur la qualité des cafés Arabica. Plantations, Recherche, Developpement, 3, 272-280.

Joet, T., Laffargue, A., Descroix, F., Doulbeau, S., Bertrand, B., De Kochko, A., \& Dussert, S. (2010). Influence of environmental factors, wet processing and their interactions on the biochemical composition of green Arabica coffee beans. Food Chemistry, 118, 693-701. http://dx.doi.org/10.1016/j.foodchem.2009.05.048

Jolliffe, I. T. (2002). Principal Component Analysis (2 ed.). Berlin: Springer.

Lingle, T. R. (2001). The coffee cupper's handbook: systematic guide to the sensory evaluation of coffee's flavor (3rd ed.). Long Beach: Specialty Coffee Association of America.

Martins, D. R., Camargo, O. A. De., \& Bataglia, O. C. (2005). Bean and beverage quality in coffee crops treated with sewage sludge. Bragantia, 64, 115-126. http://dx.doi.org/10.1590/S0006-87052005000100013

Mazzafera, P., \& Carvalho, A. (1992). Breeding for low seed caffeine content of coffee (Coffea L.) by interspecific hybridization. Euphytica, 59, 55-60.

Pereira, M. C., Chalfoun, S. M., Carvalho, G. R de., \& Savian, T. V. (2010). Multivariate analysis of sensory characteristics of coffee grains (Coffea arabica L.) in the region of upper Paranaíba. Acta Scientiarum. Agronomy, 32, 635-641. http://dx.doi.org/10.4025/actasciagron.v32i4.4283

Perrone, D., Farah, A., Donangelo, C. M., Paulis, T. de., \& Martin, P. R. (2008). Comprehensive analysis of major and minor chlorogenic acids and lactones in economically relevant Brazilian coffee cultivars. Food Chemistry, 106, 859-867. http://dx.doi.org/10.1016/j.foodchem.2007.06.053

Silva, R. F. da., Pereira, R. G. F. A., Borém, F. M., \& Silva, V. A. da. (2006). Altitude and the quality of hulled berry coffee. Revista Brasileira de Armazenamento, 9, 40-47.

Stennert, A., \& Maier, H. G. (1994). Trigonelline in coffee: II. content of green, roasted and instant coffee. $Z$. Lebensm Unters Forsch, 199, 198-200. http://dx.doi.org/10.1007/BF01193443

Villarreal, D., Laffargue, A., Posada, H., Bertrand, B., Lashermes, P., \& Dussert, S. (2009). Genotypic and environmental effects on coffee (Coffea arabica L.) bean fatty acid profile: impact on variety and origin chemometric determination. Journal of agricultural and food chemistry, 57, 11321-11327. http://dx.doi.org/10.1021/jf902441n 


\section{Copyrights}

Copyright for this article is retained by the author(s), with first publication rights granted to the journal.

This is an open-access article distributed under the terms and conditions of the Creative Commons Attribution license (http://creativecommons.org/licenses/by/3.0/). 